\title{
Exoskeleton as a New Means in Habilitation and Rehabilitation of Invalids (Review)
}

\author{
DOI: $10.17691 /$ stm2015.7.2.22
}

Received February 25, 2015

A.A. Vorobyev, MD, DSc, Professor, Head of the Department of Operative Surgery and Topographic Anatomy',

Head of the Department of Experimental and Clinical Surgery2;

A.V. Petrukhin, PhD, Assistant Professor, Department of Computer-Aided Design and Search Engineering ${ }^{3}$;

O.A. Zasypkina, PhD, Senior Tutor, Department of Operative Surgery and Topographic Anatomy Junior Researcher, Laboratory of Pathology Simulation²;

P.S. Krivonozhkina, Assistant, Department of Children Diseases, Pediatric Faculty with the Course of Pediatric Neurology';

A.M. Pozdnyakov, PhD, Assistant Professor, Department of Medical Rehabilitation and Sports Medicine with the Course of Medical Rehabilitation, Exercise Therapy, Sports Medicine, Physiotherapy, Postgraduate Faculty ${ }^{1}$

${ }^{1}$ Volgograd State Medical University, 1 Pavshikh Bortzov Square, Volgograd, 400131, Russian Federation; ${ }^{2}$ Volgograd Medical Science Center, 1 Pavshikh Bortzov Square, Volgograd, 400131, Russian Federation; ${ }^{3}$ Volgograd State Technical University, 28 Prospekt Lenina, Volgograd, 400005, Russian Federation

The problem of development and implementation of exoskeletons has been analyzed on the basis of the Russian and foreign literature. Military Industry and rehabilitation medicine are shown to be currently the priority fields of exoskeleton application. It has been noted, that the majority of the existing exoskeletons cannot be widely used for the rehabilitation of the patients with limited functions of the upper and lower limbs because they are heavy, external power supply-dependent, and expensive. Two types of exoskeletons, active and passive, have been considered. The design of the passive exoskeleton is shown to be most acceptable for use. The analysis has revealed, that the main groups requiring exoskeletons, include patients suffering from paresis of the upper and lower limbs.

Key words: passive exoskeleton; active exoskeleton; paresis; invalid.

Exoskeleton (from the Greek $\hat{\xi} \xi \omega-$ external and

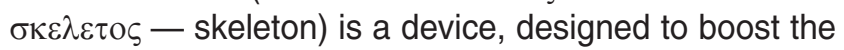
human strength by the external framework [1, 2].

There exist exoskeleton models with active and passive principle of action: active and passive exoskeletons. Active models use external units as a power source, whereas the mechanics of the passive exoskeletons relies on the kinetic energy and a human strength.

Active exoskeletons found a wide application in the Armed Forces, however, the secrecy of their development made the analysis of their design impossible. The majority of such developments belong to the Pentagon. One of the known exoskeletons, HULC (Lockheed Martin, USA) allows the soldier to move quickly with a heavy load over a rugged terrain. The HULC helps not only transfer the load, but to lift it from the ground. The device weight is $25 \mathrm{~kg}$, batteries making the main part of the load. The batteries can keep HULC operative for $2 \mathrm{~h}$. The exoskeleton design enables soldiers to carry an extra $25 \mathrm{~kg}$ of ammunition. The operation of the device is limited by climatic conditions, i.e. high or low temperature. Maintenance of the HULC may be done by the specialists only [3, 4].

XOS (Sarcos, USA) represents a specialized suit designed for the warfighters of the ground units. Its main drawback is constant connection with the power supply. Its weight, $70 \mathrm{~kg}$, also limits its use [5-7]. Both described exoskeletons are designed to enhance durability, and strength of lower and upper limbs in healthy people, such as military men.

In a number of countries the development of active exoskeletons is the subject of social projects. Their task is the compensation for the lost functions and physical and social rehabilitation of the patients. Examples are exoskeletons ReWalk, REX, HAL, eLEGS, which constructive features aim to help people with difficulties in moving.

ReWalk (ARGO Medical Technologies, Israel) enables people with paralysis of the lower part of the body (paraplegia) to walk resting on the sticks. The work of the system is based on the sensors, detecting the body bending forward and transmitting the signal to the devices supporting the legs. The cost of the apparatus is $\$ 100,000$. It is powered by the batteries, located in the special backpack. The apparatus can be used only by the people with the preserved functions of the upper limbs [8-10].

REX (REX Bionics, New Zealand) provides complementary spatial support to the human body while moving. Control is made using a joystick and control

For contacts: Vorobyev Alexandr Alexandrovich, e-mail: cos@volgmed.ru 
pad. The exoskeleton is $38 \mathrm{~kg}$, which together with a high cost, $\$ 150,000$, makes it unaffordable for a wide application [11].

HAL (Hybrid Assistive Limb, Cyberdyne, Japan) is intended for the elderly and invalids with mobility disorders. The total device weight is $23 \mathrm{~kg}$, height $160 \mathrm{~cm}$. Besides, accumulator battery weighs $10 \mathrm{~kg}$, and provides 2.5-hours of active use on a full charge at a maximum load condition. The device costs $\$ 4200$ [12].

eLEGS (Esko Bionics, USA) is a special hydraulic exoskeleton, designed for patients with partial paralysis of the low limbs. The device enables them to move with the help of crutches or special walkers. A gesture-based hardware-software interface complex uses natural human movements, translating them safely to the action of the exoskeleton through the microcomputer $[13,14]$.

An example of an active upper body exoskeleton is a fragment of an upper limb Titan Arm, designed by the engineering students at the University of Pennsylvania. The construction is compact, inexpensive in production (exoskeleton elements are made by a 3D-printer). The system is powered by the batteries which are attached to the back, and activated via cables and cords. Constructive features of this project are under patent protection, and engineering drawings are not presented [15, 16].

Passive exoskeletons found their applications mainly in the military purposes.

In Russia, Transport Walking Systems company created a passive exoskeleton $K-2$, designed for military and emergency needs [17]. This device helps a man to carry heavy loads (backpacks, body armor, sapper protection kits, fireman outfit) weighing up to $50 \mathrm{~kg}$ for a long time without great strength and load on his own musculoskeletal apparatus. Minimal dimensions and weight (from $2 \mathrm{~kg}$ ), ergonomics, and simplicity in service make the device indispensible aid in longterm expeditions, forced marches, in the regions of emergency situations. The exoskeleton is mainly made of carbon fibre, giving the device a high durability and low weight. The exoskeleton can be also used in musculoskeletal system injuries, enabling a man to move over large distances with the damaged lower limb, including fractures, by fixing it additionally to K-2 device with a gauze bandage or straps upper or lower the lesion. Exoskeleton K-2 provides complementary protection of lower limbs and spinal column from mechanical injuries. The designers of this system note the feasibility of its application for invalids with lower limb function disorders.

A group of Russian scientists at the Scientific Research Institute of Mechanics, Lomonosov Moscow State University, designed a working prototype of passive exoskeleton ExoAtlet $P$, intended for the soldiers and rescuers, allowing the wearer to carry heavy loads (70$100 \mathrm{~kg}$ ). A modification of this exoskeleton, ExoAtlet P-1, was created to relieve the load from the fighters while transferring assault shields. This exoskeleton model is equipped with the unit for fixation and fast taking off the shield, which is important in combat operations. Application of the system is indicated in the following situations [18-22]:

removal of rubble in emergency and rescue works and elimination of the consequences of natural disasters or technogenic catastrophes, firefighting with the limited air volume in the breathing apparatuses;

building construction and for the tasks, connected with carrying heavy loads over long distances;

mine clearing and counter terrorist activity;

assistance to people with physical disabilities and transporting bed patients: patients obtain the ability to walk, go up- and downstairs, sit down and stand up without any help.

The apparatus ExoAtlet $P$ is thought to be a manmachine symbiosis with mechano tactile interaction. It is an integration of a man and a robot [18].

We found the following descriptions of passive exoskeletons in the foreign literature.

A soft pneumatic exoskeleton was created by the team of researchers from Carnegie Mellon University, Harvard University, University of South Carolina, Massachusetts Institute of Technology and wearable sensor developer Bioscience. It houses flexible artificial muscles, lightweight sensors and control software. The device is made of a soft elastic polymer.

At present, it can be worn only on the low leg, the biological structure of which is diligently replicated in the device. Three cylindrical artificial muscles correspond to the muscles of the anterior and one to the posterior part of the leg. Artificial tendons (steel cables) extend from the ends of these muscles downward to the foot and serve to move the ankle.

A feedback is provided by hyperelastic strain sensors, located on the top and lateral part of the ankle. Every sensor consists of the rubber sheet, containing microchannels, filled with liquid metal-alloy conductor. The shape of these channels changes when the elastic material stretches or compresses, altering electric resistance of the metal. Once the change of the resistance is registered, the software can ascertain the position of the ankle joint.

The mobility is provided by flexible materials, but flexibility poses a certain problem: it is more difficult to control the device than the exoskeleton made of the usual rigid materials, therefore sensors must be more sensitive and the control more precise. Laboratory tests showed, that this device is able to move the ankles of the examined people within a 27-degree range of motion, which is considered sufficient enough for the normal walking gait. But this is only a prototype, and at present scientists are on the way of improving the construction to make it more convenient for the patients with movement disabilities [23-25].

Exoskeletons of this type reduce matabolic rate, 
which usually rises while walking, and therefore these devices are successfully used to teach people walking and restore the lost functions in post-stroke patients and in those who need rehabilitation after cerebrospinal traumas [28-32].

An experimental model of the upper limb exoskeleton Exoskeleton Prototype 3 (EXO-UL3, University of California, USA) owing to the drives, controlled by neuron signals of the wearer himself, enables the device to move the limb in all planes. The principle of work is as follows. An individual's wish to displace an arm (shoulder, hand) anywhere the system detects thanks to the noninvasive superficial electromyography, i.e. an array of sensors reading biocurrents controlling the muscles. The natural invisible to the eye delay between the appearance of the first myoelectric signals and an actual start of the movement of this or that muscle computer uses to calculate the probable arm displacement, using its digital model of the human limb (additionally, a feedback from the sensors of actual position and the speed of the machine parts are used). As a result the drives of the robot-suit are activated synchronously with muscle contractions and 'press' to the direction the wearer wishes to flex his arm. However, the control system (bioport) is far from being perfect [23-25]. A suit sensitive to myocurrents is capable to enhance muscle strength in people, suffering from neurodegenerative diseases, but this system, to the authors' opinion, requires further improvement [33]. Designs, similar to the described above, were used in the works of other authors who tried to eliminate some of the revealed drawbacks of the prototype [34-36].

Currently, active elaborations are being carried on aimed at filling the gap in fundamental knowledge on exoskeletons. They may be grouped according to the following main aspects:

investigations of kinematic and biomechanic properties of new apparatuses and creation on this basis optimal principles and scheme of their application [17, 37-45];

development of methods of determining systems parameters of exoskeletons and their operation control, allowing the researcher quickly and systemically evaluate different variants of the executive mechanism constructions in accordance with the criteria chosen [46-48];

application of computed analysis of virtual topographoanatomic media while designing biomechanical systems [49-57];

creation and improvement of the materials and the main units of exoskeletons, ensuring their effective performance [58-66].

The most demanded, judging by the authors' description, references to a number of works of this group of researchers and long-lasting publications on this topic, is the model developed by a team guided by Tariq Rahman from the University of Delaware [33]. The device is called WREX (Wilmington Robotic Exoskeleton). It is oriented to children with upper limb impairment, and presents a mobile system of supporting joints, which is attached to the child's active joints and muscles and is fixed to a special jacket or a wheelchair. The limbs move with a slight force and a limited amplitude in 3 dimensions.

However this exoskeleton model is available only in the USA, and requires constant adaptation to the anatomic parameters of the child. Detailed engineering information is not presented in the published materials, making its implementation practically impossible without additional investigations [67, 68].

Currently, descriptions of single investigations on exoskeletons for upper limbs can be found in Russia. Some works are at the stage of designing. A mathematic model of the human arm exoskeleton has been described with the solution of the task of direct and inverse kinematics; inaccuracy of positioning the device in the space, depending on the linear and angular errors, has been also determined [69-71].

The authors of this report have formulated clinical and anatomic criteria, which must be met by exoskeletons designed for the people with the lost functions of the upper limbs. Such requirements were not found in the available literature. The development of criteria was based on the structure and functions of a healthy arm. For this purpose, the material on the active and passive amplitude of the upper limb movements in a healthy man in case of their lost in different conditions, has been analyzed. It was established, that patients with the marked limitations of active mobility in the arms require exoskeletons, with the range of movements approaching the parameters of a healthy human:

1) the elements of the system should replicate the structure of the upper limb;

2) the device should be lightweight and strong;

3) it should be made of safety materials;

4) there must be a possibility of changing the elements as the child grows;

5) price should be affordable for mass consumers;

6) the model should be power source independent;

7) exoskeletons should perform a definite range of movements for the large joints necessary for everyday life activity.

Meeting these requirements will make it possible to create an exoskeleton model for habilitation and rehabilitation of invalids, as well as for their social adaptation [72-74]. The authors also carried out the work on the anatomic compliance of the passive upper limb exoskeleton with the original design.

Presently, exoskeletons are mainly used for rehabilitation and, to a less degree, for habilitation [75], however, a social significance of the latter direction demands widening of its capabilities for adaptation of invalids to usual life by compensating the functions, without which they cannot live independently [72-74].

A number of investigations devoted to the application of the exoskeletons of the upper limbs, can give an idea 
of a wide scope of their possible usage. In the majority of such reports treatment of post-stroke paralyses of the upper limb is considered [76-86]. Much less researches concern rehabilitation after cerebrospinal traumas [87] and in multiple sclerosis [88], in pediatric practice - for rehabilitation of the upper arm in paralyses, associated with impairment of the brachial plexus in labor [89], and in compensation of grasping function of the hand when a thumb is paralyzed [90]. However, due to the novelty of this direction no clear indications to the application of exoskeletons of the upper limbs are worked out.

Those cases, where the core of the clinical picture is a syndrome of bilateral/unilateral upper flaccid/ mixed paralysis (paresis) were of great interest for our developments. A list of these diseases was made [91-97]:

arthrogripposis - a systemic disease of the muscularskeletal system, characterized by contractures and limb deformity, underdevelopment of joints and muscles, and also by fibrosis;

mixed forms of infantile cerebral paralysis;

neuralgic amyotrophy;

spinal amyotrophy - a group of genetic diseases, characterized by the damage of the motor neurons at the level of superior horns of the spinal cord;

brachial plexopathy after Henoch-Schönlein thrombocytopenic purpur, birth trauma ("midwife paralysis", when the clavicle is broken), extra cervical ribs ("cervical rib" syndrome), Pancoast tumor (superior sulcus tumor), malposition of the upper limb during a prolonged operation period under anesthesia, granulamatous vasculopathy associated with herpes zoster virus, exogenous intoxication by dopamine;

Guillain-Barré-Strohl syndrome - acute autoimmune inflammatory demyelinizing polyradiculoneuropathy;

Larsen syndrome - a congenital disease, characteristic findings of which include multiple dislocations of the large joints, distinctive face features and skeletal malformations;

Ehlers-Danlos syndrome (collagenoses);

dystrophic dysplasia;

different forms of congenital myopathy - "central core" syndrome, nemaline myopathy, and other variants of "flaccid child" syndrome;

atonic-astatic form of infantile cerebral paralysis, mixed forms of infantile cerebral paralysis with predominance of limb muscle hypotone.

The syndrome of upper flaccid paralysis occurs in many diseases and may be the cause of invalidization. As upper limbs play the predominant role in the world learning, in patients with upper flaccid paralysis functions of social adaptation are lost, self-care becomes impossible, making the disabled completely dependent on other people [98].

Although the etiology of flaccid/mixed paralysis is various, the clinical picture in such patients seems to be typical. The main signs of this symptomatic complex, demanding exoskeleton application, are the reduction of upper limb muscle strength; restriction of the speed, volume (amplitude) of movements in the proximal and distal parts of the upper limbs with the prevalent aggravation in the proximal parts; muscle hypotonia in the proximal and distal parts of the upper limbs or mixed tonus with hypofunction predominance; low or no arm reflexes (biceps, triceps and carporadial reflexes).

According to the data of the State Statistics Committee, the quantity of people first certified as invalids amounted to $1,141,969$ or 77.6 per 10,000 of population in 2013 in Russia. Diseases leading to invalidization of population are noted at any age, but they are especially tangible among children and adolescents [99-104].

In this situation of great importance is the necessity of developing such kind of rehabilitation treatment for patients with the syndrome of upper flaccid paresis when there will be something complementary to the drug therapy, and influencing a biofeedback between the central and peripheral parts of the nervous system, and consequently, the direct connection as well.

The solution of this task becomes feasible owing to the innovative direction in bioengineering - designing and implementing upper limb exoskeletons [105-108].

Summarizing the aforesaid, the following conclusions may be made:

1. Models with active principle of work make it possible to perform a larger volume of movements, however, dependence on external power supply units, high cost, design solidity limit their wide application, including medicine. Passive exoskeletons lack these drawbacks. They are power- source-independent, therefore their weight is lower, and the reliability much higher. Price of the passive devices and their maintenance is far lower compared to their active variants.

2. The majority of the known designs are undisclosed and classified military projects. Besides, these models are often intended for healthy people (militaries).

3. An urgent task nowadays is the development of exoskeletons with wider capabilities for adaptation of invalids to everyday life by compensation for the lost functions.

Study Funding and Conflict of Interest. The work is funded by Volgograd State Medical University and Volgograd Science Center. There is no topic specific conflict of interest related to the authors of this work.

\section{References}

1. Ekzoskelet [Exoskeleton]. Vikipediya. URL: http:// ru. wikipedia.org/?oldid=67717712 (accessed: 12.02.2015).

2. Ekzoskelet - voennoe i mirnoe primenenie [Exoskeleton - military and peaceful application]. Glavnyy mekhanik 2011; 11: 50-54.

3. Bednyak S.G., Eremina O.S. Robotizirovannye ekzoskelety HAL (pochuvstvuy sebya HAL'kom). V kn.: Sbornik nauchnykh trudov Sworld. Vyp. 2. T. 1 [Robotic exoskeletons HAL (feel yourself a HAL'er). In: Collection of scientific works Sworld. Issue 2. Vol. 1]. Odessa; 2014; p. 49-51. 
4. HULC. Lockheed Martin. URL: http://www. lockheedmartin.com/us/products/hulc.html.

5. Binkiewicz-Glinska A., Sobierajska-Rek A., Bakula S., Wierzba J., Drewek K., Kowalski I.M., Zaborowska-Sapeta K. Arthrogryposis in infancy, multidisciplinary approach: case report. BMC Pediatr 2013; 13: 184, http://dx.doi. org/10.1186/1471-2431-13-184.

6. Technologies: iron soldiers. "Bratishka" zhurnal dlya spetsnaza 2011; 1: 37-41.

7. Raytheon XOS 2 exoskeleton, second-generation robotics suit, United States of America. URL: http://www. army-technology.com/projects/raytheon-xos-2-exoskeleton-us (accessed: 27.12.2014).

8. A human exoskeleton. Washington Post 2008 May 6. URL: http://www.washingtonpost.com/wp-dyn/content/article/ 2008/05/02/AR2008050203382.html.

9. Paraplegic support suits. TrendHunter. Published: Apr 4, 2008. URL: http://www.trendhunter.com/trends/helpingparaplegics-walk-rewalk-exoskeleton.

10. Rewalk' bionic legs get FDA approval. News.com. au. Published: 17 Jan, 2011. URL: http://www.news.com. au/technology/rewalk-bionic-legs-get-fda-approval/storye6frfro0-1225989332272.

11. Rosen M. Mind to motion: brain-computer interfaces promise new freedom for the paralyzed and immobile. Science News 2013; 184(10): 22-24, http://dx.doi.org/10.1002/ scin.5591841017.

12. Moreno J., Turowska E., Pons J.L. Wearable lower limb and full-body robots. In: Wearable robots: biomechatronic exoskeletons. Edited by Pons J.L. Wiley; 2008; p. 283-321.

13. eLEGSTM. Berkeley robotics and human engineering laboratory. URL: http://bleex.me.berkeley.edu/research/ exoskeleton/elegs\%E2\%84\%A2.

14. Kazerooni $\mathrm{H}$. Human augmentation and exoskeleton systems in Berkeley. Int J Human Robot 2007; 4(3): 575-605, http://dx.doi.org/10.1142/S0219843607001187.

15. Avril T. Instant strength from the Titan Arm. The Philadelphia Inquirer 2013 Jun. URL: http://titanarm.com.

16. Zolfagharifard $\mathrm{E}$. The wearable robot that turns anyone into a SUPERHERO: bionic arm lets users lift an extra 40lb effortlessly. Mail Online Published: 10 Dec, 2013. URL: http:// www.dailymail.co.uk/sciencetech/article-2521245/Titan-Armbionic-exoskeleton-lets-users-lift-extra-40lb-effortlessly.html.

17. Passive exoskeleton "K-2". Transportnye shagayushchie sistemy. URL: http://twsystem.ru/ru/node/6.

18. A medical exoskeleton for rehabilitation. ExoAtlet. URL: http://www.exoatlet.ru.

19. Russian scientists presented the first working model of an exoskeleton for assault units and emergencies rescuers. Nano News Net. Published: 22 Aug, 2013. URL: http://www. nanonewsnet.ru/news/2013/rossiiskie-uchenye-predstavilipervyi-deistvuyushchii-obrazets-ekzoskeleta-dlya-shturmovyk.

20. Vukobratovic M.K. When were active exoskeletons actually born? Int J Human Robot 2007; 3(4): 459-486, http:// dx.doi.org/10.1142/S0219843607001163.

21. On the outer suspension. Nauka i zhizn' 2013; 10: 39.

22. Avedikov G.E., Zhmakin S.I., Ibragimov V.S., Ivanov A.V., Kobrin A.I., Komarov P.A., et al. Ekzoskelet: konstruktsiya, upravlenie. V kn.: XII Vserossiyskoe soveshchanie po problemam upravleniya VSPU-2014 [Exoskeleton: design and control. In: The XII All-Russian conference on the problems of control "VSPU-2014"]. Moscow; 2014; p. 84-90.

23. Park Y.-L., Chen B., Pérez-Arancibia N.O., Young D.,
Stirling L., Wood R.J., et al. Design and control of a bio-inspired soft wearable robotic device for ankle, foot rehabilitation. Bioinspir Biomim 2014; 9(1): 016007, http://dx.doi. org/10.1088/1748-3182/9/1/016007.

24. Farris D.J., Hicks J.L., Delp S.L., Sawicki G.S. Musculoskeletal modelling deconstructs the paradoxical effects of elastic ankle exoskeletons on plantar-flexor mechanics and energetics during hopping. J Exp Biol 2014; 217(22): 40184028, http://dx.doi.org/10.1242/jeb.107656.

25. To C.S., Kobetic R., Bulea T.C., Audu M.L., Schnellenberger J.R., Pinault G., et al. Sensor-based hip control with hybrid neuroprosthesis for walking in paraplegia. J Rehabil Res Dev 2014; 51(2): 229-244, http://dx.doi. org/10.1682/JRRD.2012.10.0190.

26. Mooney L.M., Rouse E.J., Herr H.M. Autonomous exoskeleton reduces metabolic cost of human walking. $J$ Neuroeng Rehabil 2014; 11(1): 151, http://dx.doi.org/ 10.1186/1743-0003-11-151.

27. Nilsson A., Vreede K.S., Häglund V., Kawamoto H., Sankai Y., Borg J. Gait training early after stroke with a new exoskeleton - the hybrid assistive limb: a study of safety and feasibility. J Neuroeng Rehabil 2014; 11(1): 92, http://dx.doi. org/10.1186/1743-0003-11-92.

28. Murray S.A., Ha K.H., Hartigan C., Goldfarb M. Assistive control approach for a lower-limb exoskeleton to facilitate recovery of walking following stroke. IEEE Trans Neural Syst Rehabil Eng 2014; 99: 1, http://dx.doi.org/10.1109/ tnsre.2014.2346193.

29. Del-Ama A.J., Gil-Agudo A., Pons J.L., Moreno J.C. Hybrid FES-robot cooperative control of ambulatory gait rehabilitation exoskeleton. J Neuroeng Rehabil 2014; 11: 27 , http://dx.doi.org/10.1186/1743-0003-11-27.

30. Cruciger O., Schildhauer T.A., Meindl R.C., Tegenthoff M., Schwenkreis P., Citak M., Aach M. Impact of locomotion training with a neurologic controlled hybrid assistive limb (HAL) exoskeleton on neuropathic pain and health related quality of life (HRQoL) in chronic SCI. Disabil Rehabil Assist Technol 2014; 10: 1-6, http://dx.doi.org/10.3109/17483107.20 14.981875 .

31. Fleerkotte B.M., Koopman B., Buurke J.H., van Asseldonk E.H., van der Kooij H., Rietman J.S. The effect of impedance-controlled robotic gait training on walking ability and quality in individuals with chronic incomplete spinal cord injury: an explorative study. J Neuroeng Rehabil 2014; 11: 26, http://dx.doi.org/10.1186/1743-0003-11-26.

32. van Dijk W., van der Kooij $H$., van der Kooij $H$. Optimization of human walking for exoskeletal support. IEEE Int Conf Rehabil Robot 2013, http://dx.doi.org/10.1109/ ICORR.2013.6650394.

33. Rosen J., Perry J.C. Upper limb powered exoskeleton. Int J Human Robot 2007; 4(3): 529-548, http://dx.doi. org/10.1142/s021984360700114x.

34. Wang S., Wang L., Meijneke C., van Asseldonk E., Hoellinger T., Cheron G., Ivanenko Y., La Scaleia V., Sylos-Labini F., Molinari M., Tamburella F., Pisotta I., Thorsteinsson F., Ilzkovitz M., Gancent J., Nevatia Y., Hauffe R., Zanow F., van der Kooij. Design and control of the MINDWALKER exoskeleton. IEEE Trans Neural Syst Rehabil Eng 2015; 232(2): 277-286, http://dx.doi.org/10.1109/ tnsre.2014.2365697.

35. Knaepen K., Beyl P., Duerinck S., Hagman F., Lefeber D., Meeusen R. Human-robot interaction: kinematics and muscle activity inside a powered compliant knee 
exoskeleton. IEEE Trans Neural Syst Rehabil Eng 2014; 22(6): 1128-1137, http://dx.doi.org/10.1109/TNSRE.2014.2324153.

36. Shamaei K., Cenciarini M., Adams A.A., GregorczykK.N., Schiffman J.M., Dollar A.M. Design and evaluation of a quasipassive knee exoskeleton for investigation of motor adaptation in lower extremity joints. IEEE Trans Biomed Eng 2014; 61(6): 1809-1821, http://dx.doi.org/10.1109/TBME.2014.2307698.

37. Cempini M., Marzegan A., Rabuffetti M., Cortese M., Vitiello N., Ferrarin M. Analysis of relative displacement between the HX wearable robotic exoskeleton and the user's hand. J Neuroeng Rehabil 2014; 11: 147, http://dx.doi. org/10.1186/1743-0003-11-147.

38. Nasiłowski K., Awrejcewicz J., Lewandowski D. Kinematic analysis of the finger exoskeleton using MATLAB/ Simulink. Acta Bioeng Biomech 2014; 16(3): 129-134.

39. Talaty M., Esquenazi A., Briceno J.E. Differentiating ability in users of the ReWalk(TM) powered exoskeleton: an analysis of walking kinematics. IEEE Int Conf Rehabil Robot 2013, http://dx.doi.org/10.1109/ICORR.2013.6650469.

40. Ryder M.C., Sup F. Leveraging gait dynamics to improve efficiency and performance of powered hip exoskeletons. IEEE Int Conf Rehabil Robot 2013, http://dx.doi.org/10.1109/ ICORR.2013.6650440.

41. Elliott G., Sawicki G.S., Marecki A., Herr H. The biomechanics and energetics of human running using an elastic knee exoskeleton. IEEE Int Conf Rehabil Robot 2013, http://dx.doi.org/10.1109/ICORR.2013.6650418.

42. Esmaeili M., Jarrasse N., Dailey W., Burdet E., Campolo D. Hyperstaticity for ergonomie design of a wrist exoskeleton. IEEE Int Conf Rehabil Robot 2013, http://dx.doi. org/10.1109/ICORR.2013.6650417.

43. Cempini M., De Rossi S.M., Lenzi T., Cortese M., Giovacchini F., Vitiello N., Carrozza M.C. Kinematics and design of a portable and wearable exoskeleton for hand rehabilitation. IEEE Int Conf Rehabil Robot 2013, http://dx.doi. org/10.1109/ICORR.2013.6650414.

44. Ates S., Lobo-Prat J., Lammertse P., van der Kooij H., Stienen A.H. SCRIPT passive orthosis: design and technical evaluation of the wrist and hand orthosis for rehabilitation training at home. IEEE Int Conf Rehabil Robot 2013, http:// dx.doi.org/10.1109/ICORR.2013.6650401.

45. Wu T.M., Chen D.Z. Biomechanical study of upperlimb exoskeleton for resistance training with three-dimensional motion analysis system. J Rehabil Res Dev 2014; 51(1): 111126, http://dx.doi.org/10.1682/JRRD.2012.12.0227.

46. Hassan M., Kadone H., Suzuki K., Sankai Y. Wearable gait measurement system with an instrumented cane for exoskeleton control. Sensors 2014; 14(1): 1705-1722, http:// dx.doi.org/10.3390/s140101705.

47. Pehlivan A.U., Rose C., O'Malley M.K. System characterization of RiceWrist-S: a forearm-wrist exoskeleton for upper extremity rehabilitation. IEEE Int Conf Rehabil Robot 2013, http://dx.doi.org/10.1109/ICORR.2013.6650462.

48. Klauer C., Schauer T., Reichenfelser W., Karner J., Zwicker S., Gandolla M., Ambrosini E., Ferrante S., Hack M., Jedlitschka A., Duschau-Wicke A., Gfühler M., Pedrocchi A. Feedback control of arm movements using neuro-muscular electrical stimulation (NMES) combined with a lockable, passive exoskeleton for gravity compensation. Front Neurosci 2014; 8, http://dx.doi.org/10.3389/fnins.2014.00262.

49. Vereykin A.A., Koval'chuk A.K., Kulakov D.B., Semenov S.E., Karginov L.A., Kulakov B.B., Yarots V.V. Sintez kinematicheskoy skhemy ispolnitel'nogo mekhanizma ekzoskeleta. V kn.: III Mezhdunarodnaya nauchnoprakticheskaya konferentsiya "Aktual'nye voprosy nauki" [Synthesis of the kinematic scheme of the exoskeleton operating mechanism. In: The III International scientificpractical conference "Actual problems of science"]. Moscow; 2014; p. 68-76.

50. Vorob'ev A.A., Kamaev V.A., Petrukhin A.V., Egin E.I., Poroyskiy S.V., Barinov A.S., Egin M.E., Kraynev A.V., Andryushchenko F.A. Feasibility of using computer analysis of virtual topographo-anatomic media in medicine. Izvestiya Volgogradskogo gosudarstvennogo tekhnicheskogo universiteta 2006; 4: 34-35.

51. Vorob'ev A.A., Kamaev V.A., Petrukhin A.V., Egin E.I., Poroyskiy S.V., Barinov A.S., Egin M.E., Kraynev A.V., Andryushchenko F.A. Intellectualization of diagnosis procedures using computed $\mathrm{X}$-ray and magnetic resonance imaging on the basis of synthesis and analysis of virtual topographo-anatomic media. Vestnik Volgogradskogo gosudarstvennogo meditsinskogo universiteta 2005; 3: 3-6.

52. Petrukhin A.V., Zolotarev A.V. Method for automation of the initial stages of biochemical system design. Informatsionnye tekhnologii 2010; 5: 73-76.

53. Borovin G.K., Kostyuk A.V., Seet G. Computer simulation of the hydraulic control system for exoskeleton. Preprint, Inst. Appl. Math., the Russian Academy of Science; 2004.

54. Borisov A.V. Automation of rod exoskeleton design. Mekhatronika, avtomatizatsiya, upravlenie 2014; 10: 29-33.

55. Borovin G.K., Kostyuk A.V., Sit D. Mathematical simulation of the hydraulic system for exoskeleton control. Preprinty IPM im. M.V. Keldysha; 2004.

56. Cortés C., Ardanza A., Molina-Rueda F., CuestaGymez A., Unzueta L., Epelde G., Ruiz O.E., De Mauro A., Florez J. Upper limb posture estimation in robotic and virtual reality-based rehabilitation. Biomed Res Int 2014, http://dx.doi. org/10.1155/2014/821908.

57. Agarwal P., Kuo P.H., Neptune R.R., Deshpande A.D. A novel framework for virtual prototyping of rehabilitation exoskeletons. IEEE Int Conf Rehabil Robot 2013, http://dx.doi. org/10.1109/ICORR.2013.6650382.

58. Wang S., Meijneke C., van der Kooij H. Modeling, design, and optimization of Mindwalker series elastic joint. IEEE Int Conf Rehabil Robot 2013, http://dx.doi.org/10.1109/ ICORR.2013.6650381.

59. Smith R.L., Lobo-Prat J., van der Kooij H., Stienen A.H.A. Design of a perfect balance system for active upper-extremity exoskeletons. IEEE Int Conf Rehabil Robot 2013, http://dx.doi. org/10.1109/ICORR.2013.6650376.

60. Meuleman J., van Asseldonk E.H.F., van der Kooij $H$. Novel actuation design of a gait trainer with shadow leg approach. IEEE Int Conf Rehabil Robot 2013, http://dx.doi. org/10.1109/ICORR.2013.6650369.

61. Chen Y., Li G., Zhu Y., Zhao J., Cai H. Design of a 6-DOF upper limb rehabilitation exoskeleton with parallel actuated joints. Biomed Mater Eng 2014, 24(6): 2527-2535, http://dx.doi.org/10.3233/BME-141067.

62. Sylos-Labini F., La Scaleia V., d'Avella A., Pisotta I., Tamburella F., Scivoletto G., Molinari M., Wang S., Wang L., van Asseldonk E., van der Kooij H., Hoellinger T., Cheron G., Thorsteinsson F., Ilzkovitz M., Gancet J., Hauffe R., Zanov F., Lacquaniti F., Ivanenko Y.P. EMG patterns during assisted walking in the exoskeleton. Front Hum Neurosci 2014; 8: 423, http://dx.doi.org/10.3389/fnhum.2014.00423. 
63. Borisoff J.F., Mattie J., Rafer V. Concept proposal for a detachable exoskeleton-wheelchair to improve mobility and health. IEEE Int Conf Rehabil Robot 2013, http://dx.doi. org/10.1109/ICORR.2013.6650396.

64. Yu H., Huang S., Thakor N.V., Chen G., Toh S.L., Sta Cruz M., Ghorbel Y., Zhu C. A novel compact compliant actuator design for rehabilitation robots. IEEE Int Conf Rehabil Robot 2013, http://dx.doi.org/10.1109/ICORR.2013.6650478.

65. Masia L., Cappello L., Morasso P., Lachenal X., Pirrera A., Weaver P., Mattioni F. CARAPACE: a novel composite advanced robotic actuator powering assistivecompliant exoskeleton: preliminary design. IEEE Int Conf Rehabil Robot 2013; 6650511, http://dx.doi.org/10.1109/ ICORR.2013.6650511.

66. Galinski D., Sapin J., Dehez B. Optimal design of an alignment-free two-DOF rehabilitation robot for the shoulder complex. IEEE Int Conf Rehabil Robot 2013, http://dx.doi. org/10.1109/ICORR.2013.6650502.

67. Rahman T., Sample W., Jayakumar S., King M.M., Wee J.Y., Seliktar R., Alexander M., Scavina M., Clark A. Passive exoskeletons for assisting limb movement. J Rehabil Res Dev 2006; 43(5): 583-590, http://dx.doi.org/10.1682/ JRRD.2005.04.0070.

68. Rahman T., Sample W., Seliktar R., Alexander M., Scavina M. A body-powered functional upper limb orthosis. J Rehabil Res Dev 2000; 37(6): 675-680, http://dx.doi. org/10.1109/tnsre.2007.897026.

69. Gradetskiy V.G. Modelirovanie dvizheniy cheloveka dlya promyshlennykh primeneniy [Simulation of human movements for industrial applications]. Moscow; 2008.

70. Gradetskiy V.G., Ermolov I.L., Knyaz'kov M.M., Semenov E.A., Sukhanov A.N. Application of unloading elements in robot-exoskeleton design. Mekhatronika, avtomatizatsiya, upravlenie 2012; 11: 20-23.

71. Gradetskiy V.G., Ermolov I.L., Knyaz'kov M.M., Semenov E.A., Sukhanov A.N. Kinematic model of the human arm exoskeleton and positioning error determination. Mekhatronika, avtomatizatsiya, upravlenie 2014; 5: 37-41.

72. Vorob'ev A.A., Petrukhin A.V., Zasypkina O.A., Krivonozhkina P.V. Clinical and anatomic requirements to the active and passive upper limb exoskeletons. Volgogradskiy nauchno-meditsinskiy zhurnal 2014; 1: 56-61.

73. Vorob'ev A.A., Petrukhin A.V., Zasypkina O.A., Krivonozhkina P.V. The basic clinical and anatomic criteria for upper limb exoskeleton development. Zhurnal anatomii $i$ gistopatologii 2014; 1: 20-26.

74. Vorob'ev A.A., Petrukhin A.V., Zasypkina O.A., Krivonozhkina P.V. Clinical and anatomic justification of the requirements to the development of the upper limb exoskeletons. Orenburgskiy meditsinskiy vestnik 2014; 3(II): 14-18.

75. Minzdravsotsrazvitiya Rossii, Departament trudovykh otnosheniy i gosudarstvennoy grazhdanskoy sluzhby. Kontseptsiya Programmy deystviy po uluchsheniyu usloviy $i$ okhrany truda, vklyuchaya provedenie attestatsii rabochikh mest po usloviyam truda [Ministry of Health and Social Development of the Russian Federation, Department of Labor Relations and State Civil Service. A concept of the Program of actions for improvement of working conditions and labor protection, including assessment of workplaces with respect to working conditions]. Moscow; 2008.

76. Cortés C., Ardanza A., Molina-Rueda F., CuestaGómez A., Unzueta L., Epelde G., Ruiz O.E., De Mauro A., Florez J. Upper limb posture estimation in robotic and virtual reality-based rehabilitation. Biomed Res Int 2014, http://dx.doi. org/10.1155/2014/821908.

77. Mao Y., Jin X., Dutta G.G., Scholz J.P., Agrawal S.K. Human movement training with a cable driven ARm EXoskeleton (CAREX). IEEE Trans Neural Syst Rehabil Eng 2015; 23(1): 84-92, http://dx.doi.org/10.1109/TNSRE.2014.2329018.

78. Mao Y., Jin X., Agrawal S.K. Real-time estimation of glenohumeral joint rotation center with cable-driven arm exoskeleton (CAREX)-A cable-based arm exoskeleton. $J$ Mech Robot 2014; 6(1): 014502, http://dx.doi. org/10.1115/1.4025926.

79. Chang W.H., Kim Y.H. Robot-assisted therapy in stroke rehabilitation. J Stroke 2013; 15(3): 174-181, http://dx.doi. org/10.5853/jos.2013.15.3.174.

80. Klamroth-Marganska V., Blanco J., Campen K., Curt A., Dietz V., Ettlin T., Felder M., Fellinghauer B., Guidali M., Kollmar A., Luft A., Nef T., Schuster-Amft C., Stahel W., Riener R. Three-dimensional, task-specific robot therapy of the arm after stroke: a multicentre, parallel-group randomised trial. Lancet Neurol 2014; 13(2): 159-166, http://dx.doi.org/10.1016/ S1474-4422(13)70305-3.

81. Grimaldi G., Manto M. Functional impacts of exoskeleton-based rehabilitation in chronic stroke: multi-joint versus single-joint robotic training. J Neuroeng Rehabil 2013; 10: 113, http://dx.doi.org/10.1186/1743-0003-10-113.

82. Simkins M., Kim H., Abrams G., Byl N., Rosen J. Robotic unilateral and bilateral upper-limb movement training for stroke survivors afflicted by chronic hemiparesis. IEEE Int Conf Rehabil Robot 2013, http://dx.doi.org/10.1109/ ICORR.2013.6650506.

83. Weiss P., Heyer L., Munte T.F., Heldmann M., Schweikard A., Maehle E. Towards a parameterizable exoskeleton for training of hand function after stroke. IEEE Int Conf Rehabil Robot 2013; http://dx.doi.org/10.1109/ ICORR.2013.6650505.

84. Martinez J.A., Ng P., Lu S., Campagna M.S., Celik O. Design of Wrist Gimbal: a forearm and wrist exoskeleton for stroke rehabilitation. IEEE Int Conf Rehabil Robot 2013, http:// dx.doi.org/10.1109/ICORR.2013.6650459.

85. Tang Z., Sugano S., Iwata H. A finger exoskeleton for rehabilitation and brain image study. IEEE Int Conf Rehabil Robot 2013, http://dx.doi.org/10.1109/ICORR.2013.6650446.

86. Ockenfeld C., Tong R.K., Susanto E.A., Ho S.K., Hu X.L. Fine finger motor skill training with exoskeleton robotic hand in chronic stroke: stroke rehabilitation. IEEE Int Conf Rehabil Robot 2013, http://dx.doi.org/10.1109/ICORR.2013.6650392.

87. Aach M., Cruciger O., Sczesny-Kaiser M., Höffken O., Meindl R.Ch., Tegenthoff M., Schwenkreis P., Sankai Y., Schildhauer T.A. Voluntary driven exoskeleton as a new tool for rehabilitation in chronic spinal cord injury: a pilot study. Spine J 2014; 14(12): 2847-2853, http://dx.doi.org/10.1016/ j.spinee.2014.03.042.

88. Di Russo F., Berchicci M., Perri R.L., Ripani F.R., Ripani M. A passive exoskeleton can push your life up: application on multiple sclerosis patients. PLoS One 2013; 8(10): e77348, http://dx.doi.org/10.1371/journal.pone.0077348.

89. López N.M., de Diego N., Hernández R., Pérez E., Ensinck G., Valentinuzzi M.E. Customized device for pediatric upper limb rehabilitation in obstetric brachial palsy. Am J Phys Med Rehabil 2014; 93(3): 263-266, http://dx.doi.org/10.1097/ PHM.0b013e3182a51c95.

90. Aubin P.M., Sallum H., Walsh C., Stirling L., Correia A. Apediatric robotic thumb exoskeleton for at-home rehabilitation: 
the Isolated Orthosis for Thumb Actuation (IOTA). IEEE Int Conf Rehabil Robot 2013, http://dx.doi.org/10.1109/ ICORR.2013.6650500.

91. Arthrogryposis: a text atlas. Edited by Staheli L.T., Hall J.G., Jaffe K.M., Paholke D.O. Cambridge University Press; 1998.

92. Agras P.I., Guveloglu M., Aydin Y., Yakut A., Kabakus N. Lower brachial plexopathy in a child with Henoch-Schönlein purpura. Pediatr Neurol 2010; 42(5): 355-358, http://dx.doi. org/10.1016/j.pediatrneurol.2010.01.010.

93. Binienda Z.K., Sarkar S., Mohammed-Saeed L., Gough B., Beaudoin M.A., Ali S.F., Paule M.G., Imam S.Z. Chronic exposure to rotenone, a dopaminergic toxin, results in peripheral neuropathy associated with dopaminergic damage. Neurosci Lett 2013; 541: 233-237, http://dx.doi.org/10.1016/ j.neulet.2013.02.047.

94. Coste B., Houge G., Murray M.F., Stitziel N., Bandell M., Giovanni M.A., Philippakis A., Hoischen A., Riemer G., Steen U., Steen V.M., Mathur J., Cox J., Lebo M., Rehm H., Weiss S.T., Wood J.N., Maas R.L., Sunyaev S.R., Patapoutian A. Gain-of-function mutations in the mechanically activated ion channel PIEZO2 causea subtype of Distal Arthrogryposis. Proc Natl Acad Sci USA 2013; 110(12): 46674672, http://dx.doi.org/10.1073/pnas.1221400110.

95. Fleming J., Fogo A., Haider S., Diaz-Cano S., Hay R., Bashir S. Varicella zoster virus brachioplexitis associated with granulomatous vasculopathy. Clin Exp Dermatol 2013; 38(4): 378-381, http://dx.doi.org/10.1111/ced.12096.

96. Kany J., Kumar H.A., Amaravathi R.S., Abid A., Accabled F., de Gauzy J.S., Cahuzac J.P. A subscapularispreserving arthroscopic release of capsule in the treatment of internal rotation contracture of shoulder in Erb's palsy (SPARC procedure). J Pediatr Orthop B 2012; 21(5): 469-473, http:// dx.doi.org/10.1097/BPB.0b013e328353a19f.

97. van Alfen N. Clinical and pathophysiological concepts of neuralgic amyotrophy. Nat Rev Neurol 2011; 7(6): 315-322, http://dx.doi.org/10.1038/nrneurol.2011.62.

98. Mironenko V.P., Vergunova N.S. Concept of optimal movement model for disabled people. Vestnik Khar'kovskoy gosudarstvennoy akademii dizayna $i$ iskusstv 2014; 3: 20-23.

99. Frolov A.A. Principles of neurorehabilitation based on the usage of "brain-computer" interface and biologically adequate exoskeleton control. Fiziologiya cheloveka 2013; $39(2): 99-113$
100. Leshchenko Ya.A., Batura O.G., Lebedeva L.N. Mortality rate of the working-age population Problemy sotsial'noy gigieny, zdravookhraneniya i istorii meditsiny 2008; 3: 23-25.

101. D'yachenko V.G., Rzyankina M.F., Solokhina L.V. Rukovodstvo po sotsial'noy pediatrii [Manual on the Social Pediatrics]. Khabarovsk; 2010.

102. Ovcharenko S.A. Sotsial'no-gigienicheskaya kharakteristika faktorov riska invalidizatsii naseleniya aktivnogo trudosposobnogo vozrasta. V kn.: Aktual'nye problemy invalidnosti [Social and hygienic characteristics of risk-factors of active working-age population invalidization. In: Actual problems of disability]. Moscow; 2004/1991; p. 48-51.

103. Baranov A.A., Shcheplyagina L.A., Il'in A.G. Cildren health condition as a national security factor. Rossiyskiy pediatricheskiy zhurnal 2005; 2: 4-8.

104. Baranov A.A. Current scientific and practical problems of Russian Pediatrics. Pediatriya 2005; 3: 4-7.

105. Balashova L.M. Analysis of strategies, used in the rehabilitation process by the families, bringing-up disabled children. Izvestiya Rossiyskogo gosudarstvennogo pedagogicheskogo universiteta im. A.I. Gertsena: Aspirantskie tetradi 2007; 17(43-2): 23-26.

106. Astur N., Flynn J.M., Flynn J.M., Ramirez N., Glotzbecker M., van Bosse H.J., Hoashi J.S., d'Amato C.R., Kelly D.M., Warner W.C. Jr., Sawyer J.R. The efficacy of rib-based distraction with VEPTR in the treatment of earlyonset scoliosis in patients with arthrogryposis. J Pediatr Orthop 2014; 34(1): 8-13, http://dx.doi.org/10.1097/ BPO.0b013e3182a00667.

107. Solov'eva K.S., Bityukov K.A. Problema detskoy invalidnosti $v$ svyazi $s$ ortopedicheskoy patologiey i zadachi ortopeda pri provedenii meditsinskoy reabilitatsii. V kn.: Optimal'nye tekhnologii diagnostiki $i$ lecheniya $v$ detskoy travmatologii i ortopedii, oshibki i oslozhneniya [The problem of children disability related to orthopedic pathology and orthopedist's tasks in the course of medical rehabilitation. In: Optimal technologies of diagnosis and treatment in pediatric traumatology and orthopedics, errors and complications]. Saint Petersburg; 2003; p. 13-16.

108. Makarova M.R., Lyadov K.V., Turova E.A., Kochetkov A.V. Feasibilities of modern mechanotherapy in the correction of movement disorders in neurological patients. Vestnik vosstanovitel'noy meditsiny 2014; 1: 54-62. 